\title{
NOISE POLLUTION ASSESSMENT IN GREATER AGARTALA CITY: A CASE STUDY
}

\author{
Pulakesh Sen ${ }^{1}$, Abir Bhattacherjee ${ }^{2}$, Abhijit Das ${ }^{3}$, Debabrata Das ${ }^{4}$ \\ ${ }^{I}$ M. Tech Scholar, Department of Civil Engineering, National Institute of Technology, Agartala, India \\ ${ }^{2}$ M. Tech Scholar, Department of Civil Engineering, National Institute of Technology, Agartala, India \\ ${ }^{3}$ M. Tech Scholar, Department of Civil Engineering, National Institute of Technology, Agartala, India \\ ${ }^{4}$ M. Tech Scholar, Department of Civil Engineering, National Institute of Technology, Agartala, India
}

\begin{abstract}
The influx of people towards the cities and urban centre has resulted rapid urbanization across the country. The large rate of urbanization coupled with population migration changed the environmental scenario of many towns \& cities very abruptly. Management of municipal solid waste, reduction of air pollution from various sources, water and wastewater management, control and abatement of noise pollution etc are the big challenges. Besides, reckless use of horns and continuous vehicular movement results the noise pollution problem in many cities. The present study is an attempt to evaluate noise pollution load of Agartala city due to urbanization activities and its detrimental effect on the human health and environment. The study also seek a solution from the noise pollution problems of the Agartala City by making certain restriction on the use of sound generating instruments, mass awareness among people and regular enforcement of Noise Pollution (Prevention \& Control) Rules 2000.
\end{abstract}

Keywords: Urbanization, Noise pollution, Equivalent noise level, Evaluation, Agartala city

$* * *$

\section{INTRODUCTION}

As per the census report 2011, a sum of 377 million people lives in 7935 urban centre in India. The influx of people towards the cities and urban centre are mainly in search of livelihood and better infrastructure amenities. There is no exception in Agartala city also. Rapid influx of population has resulted Agartala City into large rate of urbanization. The population in Agartala was 157358 in the year 1991. Now, the present population is approximately 400000. Due to its large rate of urbanization coupled with population migration, the scenario of Agartala has changed very rapidly in terms of infrastructure, connectivity and other allied sectors. The environmental condition of the city has been changing abruptly along with the rapid growth of urbanization. Management of municipal solid waste, reduction of air pollution from various sources, water and wastewater management, control and abatement of noise pollution etc are the big challenges. Besides, reckless use of horns and continuous vehicular movement results the noise pollution problem in the city. This apart, industrial development, growth of commercial complexes, huge crowed, construction and demolition of buildings activities etc generated the considerable noises which are posing serous noise pollution problems in the city. The present study is an attempt to evaluate noise pollution load of Agartala city due to urbanization activities and its detrimental effect on the human health and environment.

Numerous studies have already been conducted to evaluate the noise pollution load in many towns and cities. A study on the different level of noise pollution in the Dhaka city was conducted by Hassan et al. (2013). The noise levels in the major intersection of the Dhaka city was analyzed reflecting to the major entities such as hospitals, educational institution; religious institutions [1]. Jamrah et al., in 2005 conducted an evaluative study based on the road traffic condition in the city of Amman, Jordan. A total no of 28 sampling sites were studied two times a day for a period of one hour. Data collected during the early morning and early evening rush hours was standaralised using Road traffic noise index $\mathrm{L}_{10}(1 \mathrm{~h})$. The traffic volume, percentage of heavy vehicles, road surface, intervening ground are taken in to considerations for prediction of Road traffic Noise model [2]. In order to measure the environmental noise levels and also to assess noise pollution level due to traffic mobility in the Banepa, a semi urban town of Nepal, a study was conducted by Murthy et al. (2007). Results showed that Bapena municipal city is highly affected by noise pollution [3]. Sampath et al., (2004) conducted a survey to assess noise pollution in three different cities of kerala,viz. thiruvananthapuram, kochi and Kozhikode. The data were collected from the commercial places of the three cities which are higher than the prescribed noise limit. The Leq method of sound level rating was followed under this study [4]. A study to analyze the level of noise pollution in Abuja, capital of Nigeria was conducted by Anomohanran (2013). The data was taken from around 35 sampling station in the city with the help of integrated sound level meter. The study shows that the Central business district of the city was highly exposed to the highest day-night noise value. Daytime sound level implies that numerous industries activities are going on within a short period of time and in a close range of distance [5]. Mangalekar et al. (2012) has conducted a study on noise pollution in Kolhapur City, Maharashtra, India. The noise levels are surveyed on 8 stations in Kolhapur city. The average noise level observed 
from industrial, commercial, residential and silence area are higher sound level than the prescribed limits of Central Pollution Control Board due to increase in number of moving vehicles [6]. Haq et al. (2012) has conducted a GIS based study of noise pollution in mixed areas of Dhaka City, Bangladesh. The data analysis and interpretation were done by applying GIS (Arc GIS 9.2) software. Result showed that noise pollution in Dhaka city is a very big problem Specially Ramna area is seriously affected [7].

\section{DESCRIPTION OF SITE}

Agartala is the capital of Tripura State, India. It is situated between latitude $23^{0} 50^{\circ} \mathrm{N} \&$ longitude $91^{\circ} 16^{\prime} \mathrm{E}$. Administratively, the capital Agartala is located under the West Tripura District, Tripura. India. Agartala Municipal Corporation is one of the urban local bodies looking after the various development projects of the Agartala City. It is the largest town by means of population as well as area in Tripura. The historical place Agartala consists of lots of commercial Centre's, historic temples and antique monuments. It has a geographic area of about $76.504 \mathrm{~km}^{2}$. Topographically, Agartala City is located in western part of Tripura and situated on the both banks of Haora River. An international boundary is also located $2 \mathrm{~km}$ away. It has an average elevation of $12 \mathrm{~m}$ from the nearest sea level. A large availability of plain land in Agartala city is also causing an important role in rapid growth of industries as well as different commercial places. There is a NH-44 which connects the state capital with other Indian neighboring States such as Assam \& Mizoram. There are many other roads which connect the Agartala city with other parts of the State. Moreover, there is one Railway Station which is located within the municipality area. The Agartala airport is located at an aerial distance of $12 \mathrm{~km}$ from Agartala City.

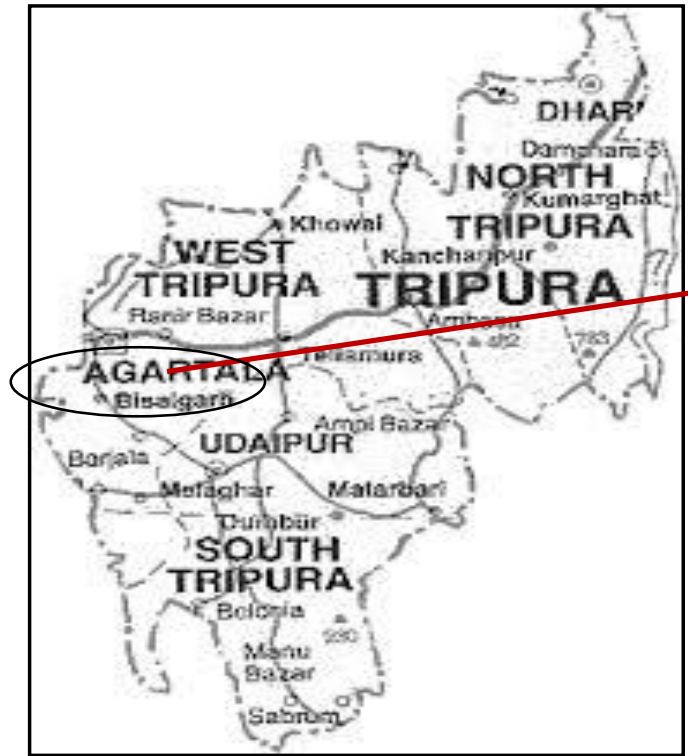

Fig: Map of Tripura

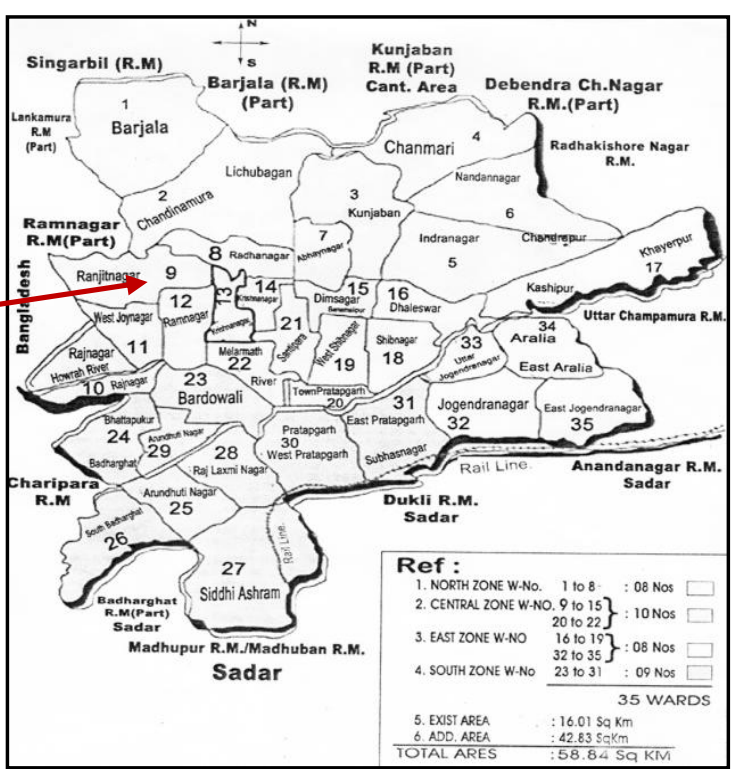

Fig: Sketch of Agartala Municipal Corporation

\section{MATERIALS AND METHODS:}

In order to assess the distribution of noise level, field level noise monitoring was carried out in major noisy area of 19 locations within the Agartala city. Every location has been selected on the basis of magnitude of noise in respect of residential, commercial, Industrial and silent zones. In order to evaluate the distribution of noise intensity in each category of zone, 4 locations have chosen for the category of residential area, 4 locations for Industrial area and 4 locations under the silent zone's category. Besides, there are 7 identified locations have considered for the commercial area as the majority of commercial areas are highly exposed to the potential noise pollution. Noise level was measured in seven different hours in a day between 6 am to $7 \mathrm{am}, 9 \mathrm{am}$ to $10 \mathrm{am}, 12$ am to $1 \mathrm{pm}, 3 \mathrm{pm}$ to $4 \mathrm{pm}, 6 \mathrm{pm}$ to $7 \mathrm{pm}, 9 \mathrm{pm}$ to $10 \mathrm{pm}$ and $11 \mathrm{pm}$ to $12 \mathrm{pm}$. The noise monitoring was conducted during the pre-monsoon period of the year 2014. Ambient noise data was recorded by using Sound Level Meter. Monitoring was carried out by mounting the

instrument at $1 \mathrm{~m}$ height and $1 \mathrm{~m}$ away from the chest. Sound level ranges of $30-180 \mathrm{~dB}(\mathrm{~A})$ was used for the study. Measured sound level data are interpreted in the form of equivalent sound level pressure $\left(\mathrm{L}_{\mathrm{eq}}\right)$ and the values of $\mathrm{L}_{\mathrm{eq}}$ are being compared with the prescribed standard of $\mathrm{CPCB}$ (Central Pollution Control Board), India [8]. Observed sound level data were used to calculate the day time equivalent noise level, night time equivalent noise level, day-night equivalent noise level, $\mathrm{L}_{10}, \mathrm{~L}_{50}, \mathrm{~L}_{90}, \mathrm{~L}_{\max }$ and traffic noise index. The calculations were made based on the following equations.

$$
L_{e q}=10 \log \sum_{i=1}^{n}(10)^{L_{i}} / 10 * t_{i} \ldots \ldots \ldots \ldots \ldots \text { [9]. }
$$

Where, $\mathrm{L}_{\mathrm{eq}}=$ Equivalent noise level, $\mathrm{n}=$ total number of sound sample, $\mathrm{L}_{\mathrm{i}}=$ noise level of any $\mathrm{i}^{\text {th }}$ sample, $\mathrm{t}_{\mathrm{i}}=$ time duration of $i^{\text {th }}$ sample expressed as fraction of total time. 


$$
L_{d n}=10\left[\log \frac{1}{24}\left\{15 *\left(10^{L_{d} / 10}\right)\right\}+9 *\left\{10^{\left(L_{n}+10\right)} / 10\right\}\right]
$$$$
\text { ............. [5]. }
$$

Where, $\mathrm{L}_{\mathrm{dn}}=$ Day-night level, $\mathrm{L}_{\mathrm{d}}=$ Day time noise level, $\mathrm{L}_{\mathrm{n}}$ $=$ Night time noise level, Lmax = Maximum noise level obtained for a particular place at measuring time and Traffic Noise Index $(\mathrm{TNI})=4\left(\mathrm{~L}_{10}-\mathrm{L}_{90}\right)+\mathrm{L}_{90}-\mathrm{L}_{30}$. [Considering 15 hour day time, from 6 am to $9 \mathrm{pm}$ and remaining 9 hour as night time, from $9 \mathrm{pm}$ to $6 \mathrm{am}$ ]
So far $\mathrm{L}_{10}, \mathrm{~L}_{50}, \mathrm{~L}_{90}$ are concerned, the noise level exceeded for $10 \%$ of the time of the measured duration is referred as $\mathrm{L}_{10}$. Similarly, $\mathrm{L}_{50}$ means noise level exceeded for $50 \%$ of the time of the measured duration, $\mathrm{L}_{90}$ means noise level exceeded for $90 \%$ of the time of the measured duration. $\mathrm{L}_{\max }$ refers maximum value of noise level obtained from particular station.

Table- 1: The Ambient Air Quality Standards prescribed by CPCB

\begin{tabular}{|l|l|l|}
\hline \multirow{2}{*}{ Category of Area / Zone } & \multicolumn{2}{|l|}{ Limit of equivalent noise level, dB(A) $\mathrm{L}_{\mathrm{eq}}{ }^{*}$} \\
\cline { 2 - 3 } & Day Time $(6.00 \mathrm{am}$ to $10.00 \mathrm{pm})$ & Night Time $(10 \mathrm{pm}$ to $6 \mathrm{am})$ \\
\hline Silent Zone & 50 & 40 \\
\hline Residential Zone & 55 & 45 \\
\hline Commercial Zone & 65 & 55 \\
\hline Industrial Area & 75 & 70 \\
\hline
\end{tabular}

$* \mathrm{~dB}(\mathrm{~A})$ Leq, denotes the time weighted average of the sound level in decibels on scale A which is relatable to human hearing.

\section{RESULTS AND DISCUSSION}

The interpreted noise data for residential indicates that highest noise level of $63.79 \mathrm{~dB}(\mathrm{~A})$ was observed at Bordowali and lowest $54.98 \mathrm{~dB}(\mathrm{~A})$ observed at Abhoynagar during day time. On the other hand, night time noise level of maximum $47.67 \mathrm{~dB}(\mathrm{~A})$ reported at Bordawali and lowest $45.43 \mathrm{~dB}(\mathrm{~A})$ reported at Dhaleswar. The interpreted values of $\mathrm{L}_{\mathrm{d}}, \mathrm{L}_{\mathrm{n}}, \mathrm{L}_{\mathrm{dn}}, \mathrm{L}_{10}, \mathrm{~L}_{50}, \mathrm{~L}_{90}, \mathrm{~L}_{\max }$, TNI in respect of residential area are presented in table-2. As the locations namely Ramnagar, Bordawali, A. D. Nagar and Abhoynagar are situated in thickly populated residential area; hence human crowed, congested houses etc. are playing important role for noise generation. However, night time noises are much below than the day time noise.

Table-2: Noise data of Residential Area in $\mathrm{dB}(\mathrm{A})$

\begin{tabular}{|c|c|c|c|c|c|c|c|c|c|}
\hline Sl. No. & Location & $\mathrm{L}_{\mathrm{d}}$ & $\mathrm{L}_{\mathrm{n}}$ & $\mathrm{L}_{\mathrm{dn}}$ & $\mathrm{L}_{10}$ & $\mathrm{~L}_{50}$ & $\mathrm{~L}_{90}$ & $\mathrm{~L}_{\max }$ & TNI \\
\hline 1 & Abhoynagar & 54.98 & 46.62 & 55.67 & 55.67 & 53.62 & 40.25 & 63.8 & 71.93 \\
\hline 2 & Dhaleswar & 58.30 & 45.43 & 57.43 & 57.21 & 54.7 & 42.3 & 65.07 & 71.94 \\
\hline 3 & Ramnagar & 56.46 & 46.41 & 56.44 & 56.60 & 52.17 & 39.8 & 69.03 & 77 \\
\hline 4 & Bordawali & 63.79 & 47.67 & 62.34 & 59.67 & 53.05 & 41.2 & 68.31 & 85.08 \\
\hline
\end{tabular}

The interpreted value of $L_{d}$ shows that the high elevated noise in Silence Zones during day time. Agartala Govt. Medical College is the biggest hospital of Tripura State and IGM hospital both located within the area of Agartala city. Both hospitals are exposed to noise pollution during day time. However, the $L_{n}$ values are found to be very less except $46.48 \mathrm{~dB}(\mathrm{~A})$ reported at Agartala Govt, Medical College. The interpreted values of $\mathrm{L}_{\mathrm{d}}, \mathrm{L}_{\mathrm{n}}, \mathrm{L}_{\mathrm{dn}}, \mathrm{L}_{10}, \mathrm{~L}_{50}, \mathrm{~L}_{90}$, $\mathrm{L}_{\text {max }}$, TNI in respect of Silence Zones are presented in table3:

Table-3: Noise data of Silence Zones in $\mathrm{dB}(\mathrm{A})$

\begin{tabular}{|l|l|l|l|l|l|l|l|l|l|}
\hline $\mathrm{S} / \mathrm{N}$ & Location & $\mathrm{L}_{\mathrm{d}}$ & $\mathrm{L}_{\mathrm{n}}$ & $\mathrm{L}_{\mathrm{dn}}$ & $\mathrm{L}_{10}$ & $\mathrm{~L}_{50}$ & $\mathrm{~L}_{90}$ & $\mathrm{~L}_{\max }$ & $\mathrm{TNI}$ \\
\hline 1 & M.B.B. College & 55.44 & 38.46 & 53.89 & 56.27 & 50.67 & 40.89 & 64.5 & 72.41 \\
\hline 2 & I.G.M. Hospital & 57.01 & 38.79 & 55.34 & 58.15 & 54.17 & 39.32 & 66.20 & 84.64 \\
\hline 3 & Shishu Bihar School & 59.06 & 39.38 & 57.05 & 60.83 & 49.68 & 41.53 & 65.87 & 88.73 \\
\hline 4 & Agartala Govt Medical College & 60.002 & 46.48 & 58.07 & 62.03 & 56.93 & 48.17 & 71.2 & 73.61 \\
\hline
\end{tabular}

The distribution of noise intensity in the form of $\mathrm{L}_{\mathrm{d}}, \mathrm{L}_{\mathrm{n}}, \mathrm{L}_{\mathrm{dn}}$, $\mathrm{L}_{10}, \mathrm{~L}_{50}, \mathrm{~L}_{90}, \mathrm{~L}_{\max }$, TNI in respect of industrial areas are evaluated and presented in table-4. The maximum sound level pressure $\mathrm{L}_{\mathrm{d}}$ value of $75.95 \mathrm{~dB}(\mathrm{~A})$ is observed at the Khayerpur Wood based Industry in day time. However, the values of $\mathrm{L}_{\mathrm{n}}$ are found considerable declined at two stations during night time. The day time noise is coming out mainly from due to industrial activities. 
Table-4: Noise data of Industrial Areas in $\mathrm{dB}(\mathrm{A})$

\begin{tabular}{|c|c|c|c|c|c|c|c|c|c|}
\hline $\mathrm{S} / \mathrm{N}$ & Location & $\mathrm{L}_{\mathrm{d}}$ & $\mathrm{L}_{\mathrm{n}}$ & $\mathrm{L}_{\mathrm{dn}}$ & $\mathrm{L}_{10}$ & $\mathrm{~L}_{50}$ & $\mathrm{~L}_{90}$ & $\mathrm{~L}_{\max }$ & TNI \\
\hline 1 & A.D.Nagar Industrial Estate & 71.56 & 47.27 & 69.61 & 74.33 & 63.37 & 51.6 & 79.21 & 112.52 \\
\hline 2 & Dukli Industrial Estate & 70.5 & 48.78 & 68.63 & 72.45 & 61.7 & 50.57 & 78.5 & 108.09 \\
\hline 3 & Barjala Wood based Industry & 72.47 & 50.56 & 70.59 & 73.69 & 62.83 & 49.35 & 80.75 & 116.71 \\
\hline 4 & Khayerpur Wood based Industry & 75.95 & 54.11 & 74.07 & 79.13 & 68.87 & 55.47 & 85.36 & 120.11 \\
\hline
\end{tabular}

Analysis of recent noise data reveals that the $\mathrm{L}_{\mathrm{d}}$ values of all the locations are found beyond the prescribed noise limit of $65 \mathrm{~dB}(\mathrm{~A})$ in day time. The maximum $\mathrm{L}_{\mathrm{d}}$ values of $79.55 \mathrm{~dB}$ (A) is observed at the Nagerjala Motor stand in day time. The $\mathrm{Ld}$ value of $65.61 \mathrm{~dB}(\mathrm{~A})$ reported at Agartala City centre. The values of $\mathrm{Ln}$ of all the locations are also found beyond the prescribed noise limit of $55 \mathrm{~dB}(\mathrm{~A})$ during night time except $52.56 \mathrm{~dB}(\mathrm{~A})$ reported at Lake Chowmuni Bazar. Continuous vehicular movement, human crowed, uses of loudspeaker etc are the various sources that cause noise pollution in commercial areas. The values of $\mathrm{L}_{\mathrm{d}}, \mathrm{L}_{\mathrm{n}}, \mathrm{L}_{\mathrm{dn}}, \mathrm{L}_{10}$, $\mathrm{L}_{50}, \mathrm{~L}_{90}, \mathrm{~L}_{\max }, \mathrm{TNI}$ in respect of commercial areas are evaluated and presented in table-5.

Table-5: Noise data of Commercial Areas in $\mathrm{dB}(\mathrm{A})$

\begin{tabular}{|l|l|l|l|l|l|l|l|l|l|}
\hline $\mathrm{S} / \mathrm{N}$ & Location & $\mathrm{L}_{\mathrm{d}}$ & $\mathrm{L}_{\mathrm{n}}$ & $\mathrm{L}_{\mathrm{dn}}$ & $\mathrm{L}_{10}$ & $\mathrm{~L}_{50}$ & $\mathrm{~L}_{90}$ & $\mathrm{~L}_{\max }$ & TNI \\
\hline 1 & Battala Bazar & 75.12 & 62.79 & 73.22 & 75.04 & 69.54 & 51.19 & 82.49 & 116.59 \\
\hline 2 & Nagerjala Motor stand & 79.55 & 56.9 & 77.65 & 80.31 & 71.28 & 57.12 & 90.25 & 119.88 \\
\hline 3 & Lake Chowmuni Bazar & 70.02 & 52.56 & 68.42 & 75.49 & 64.10 & 52.27 & 79.83 & 115.37 \\
\hline 4 & Golbazar & 75.78 & 61.03 & 74.5 & 76.28 & 68.19 & 59.73 & 88.52 & 95.93 \\
\hline 5 & Agartala City centre & 65.61 & 56.58 & 63.88 & 70.57 & 62.47 & 51.45 & 75.62 & 97.93 \\
\hline 6 & Chandrapur Motor Stand & 72.28 & 56.55 & 70.88 & 74.06 & 65.71 & 58.91 & 84.01 & 89.51 \\
\hline 7 & Post-office Chowmuni & 71.45 & 58.56 & 70.57 & 72.97 & 62.5 & 47.21 & 82.07 & 102.25 \\
\hline
\end{tabular}

The variation of the intensity of sound in different places due to presence of congested houses, huge commercial centers, other small and large scale industry, VIP areas, Industrial Estate at the outskirt of the city, large no of schools and colleges, presence of NH-44, Railway station, Airport etc. Moreover, construction activities are also playing an important role towards contribution of noise pollution load in and around the Agartala City. The calculated noise level parameters and its distribution in respect of different categories of area are graphically illustrated in Fig 1 to Fig. 6.

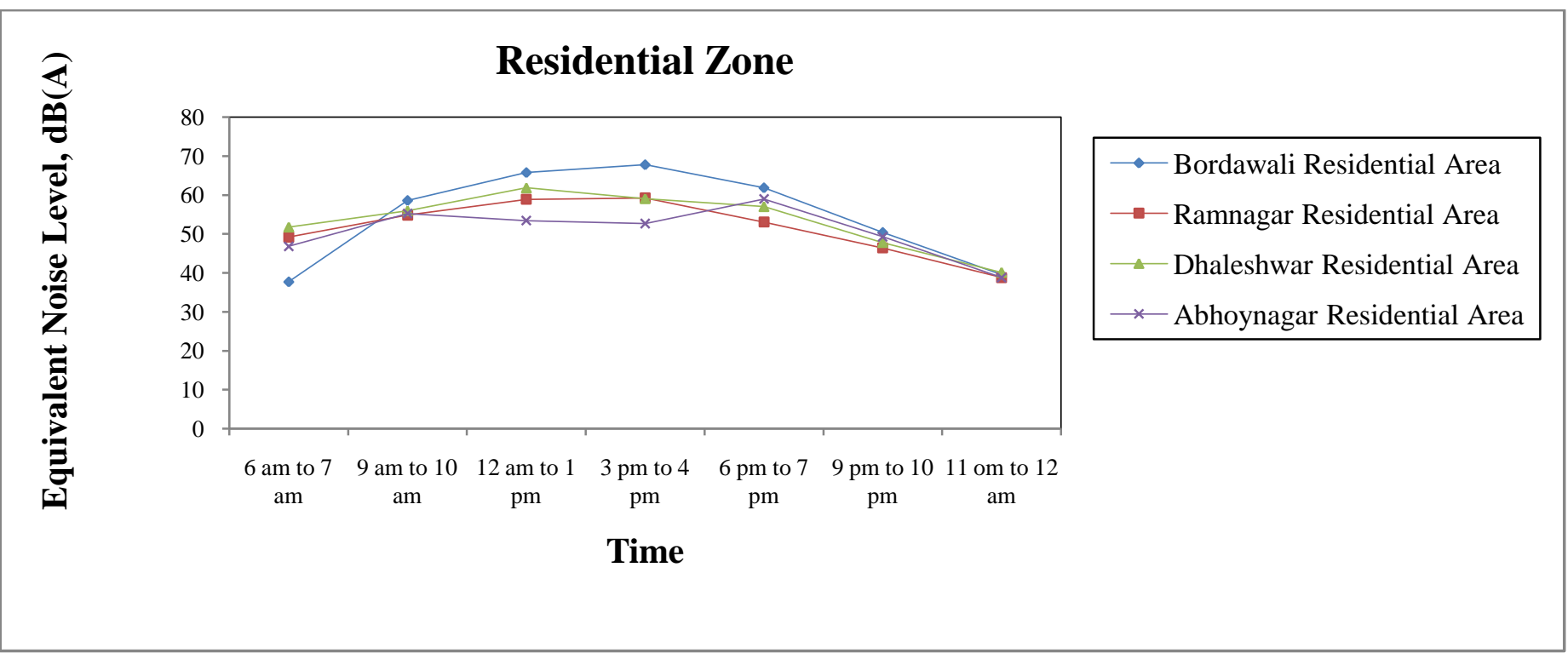

Fig: 5 Equivalent Noise Level 


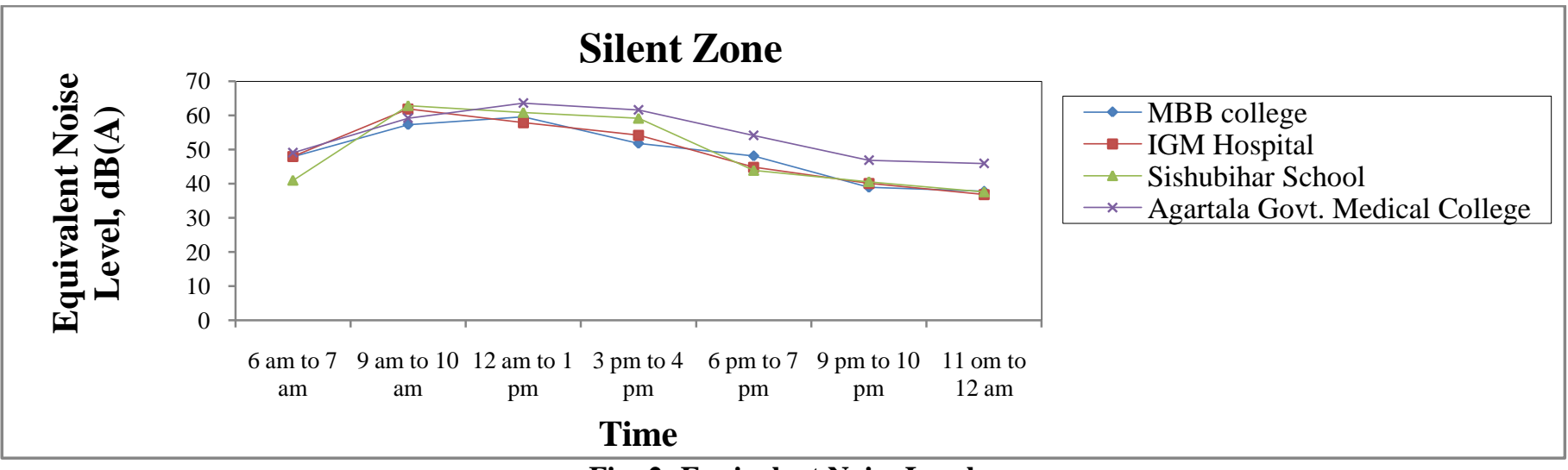

Fig: 2: Equivalent Noise Level

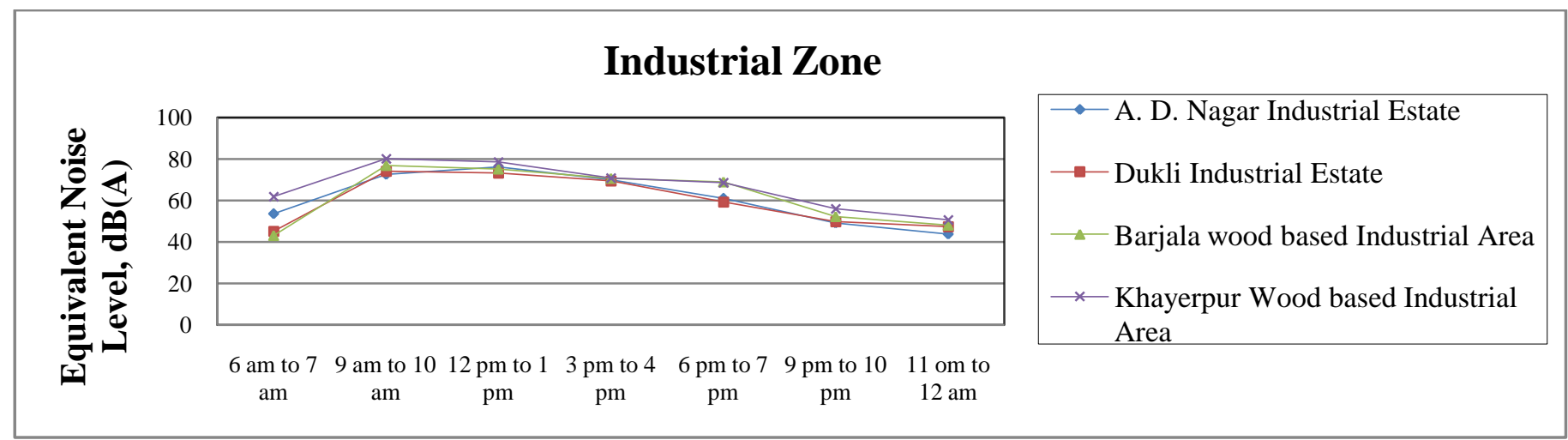

Fig: 3 Euuivalent Noise Level

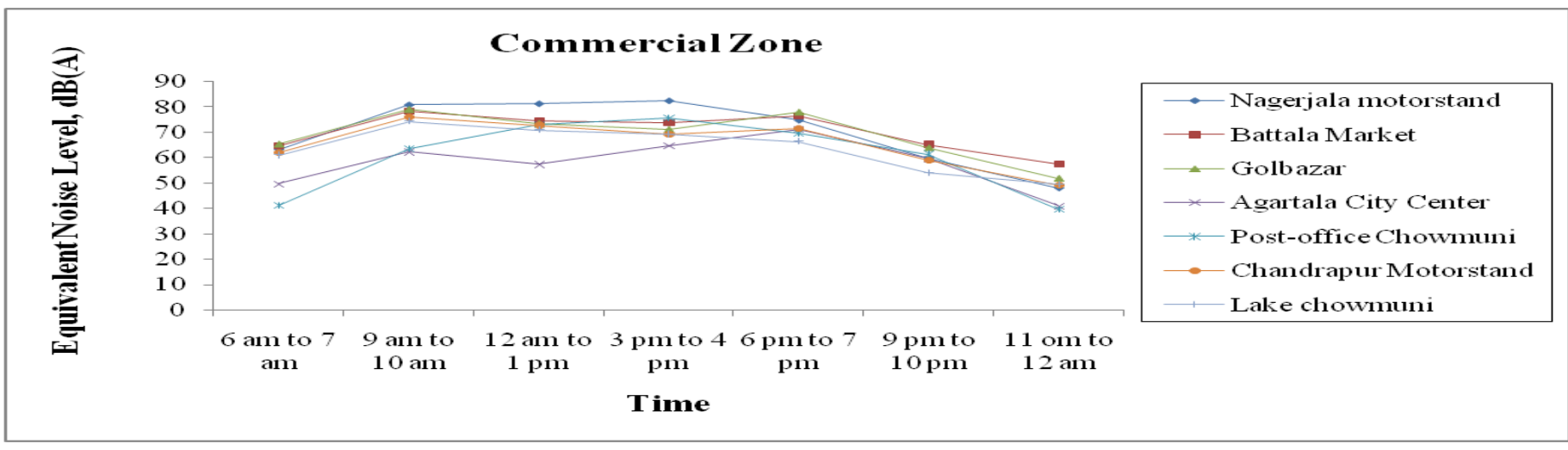

Fig: 4 Equivalent Noise Level

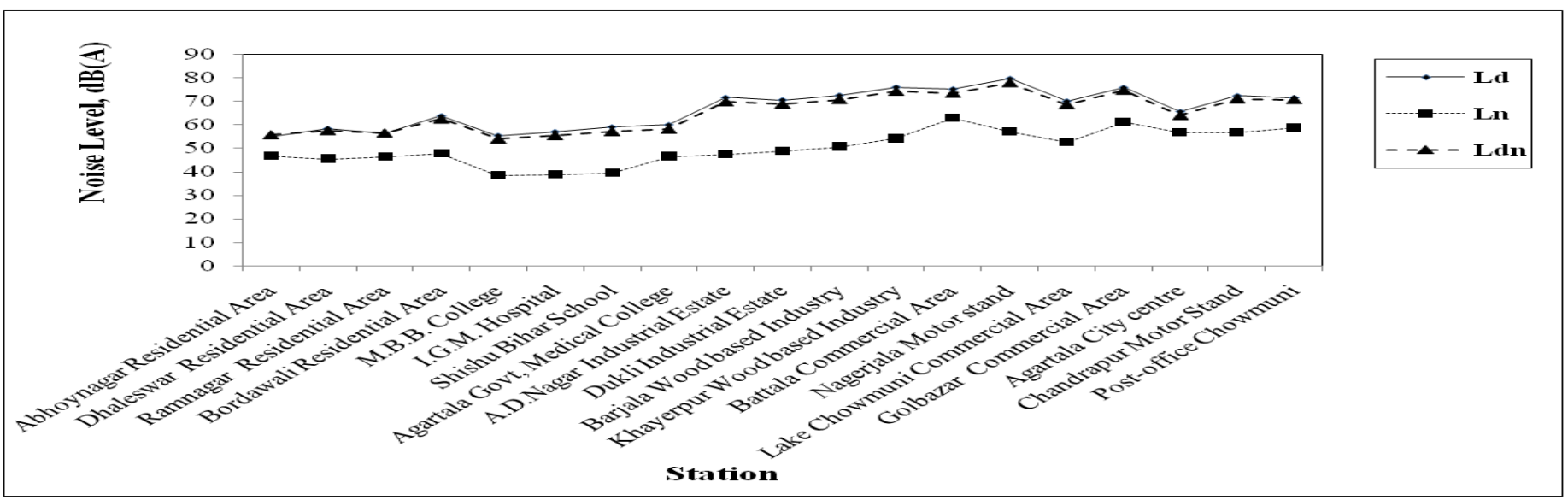

Fig: 5 Noise Levels at different places 


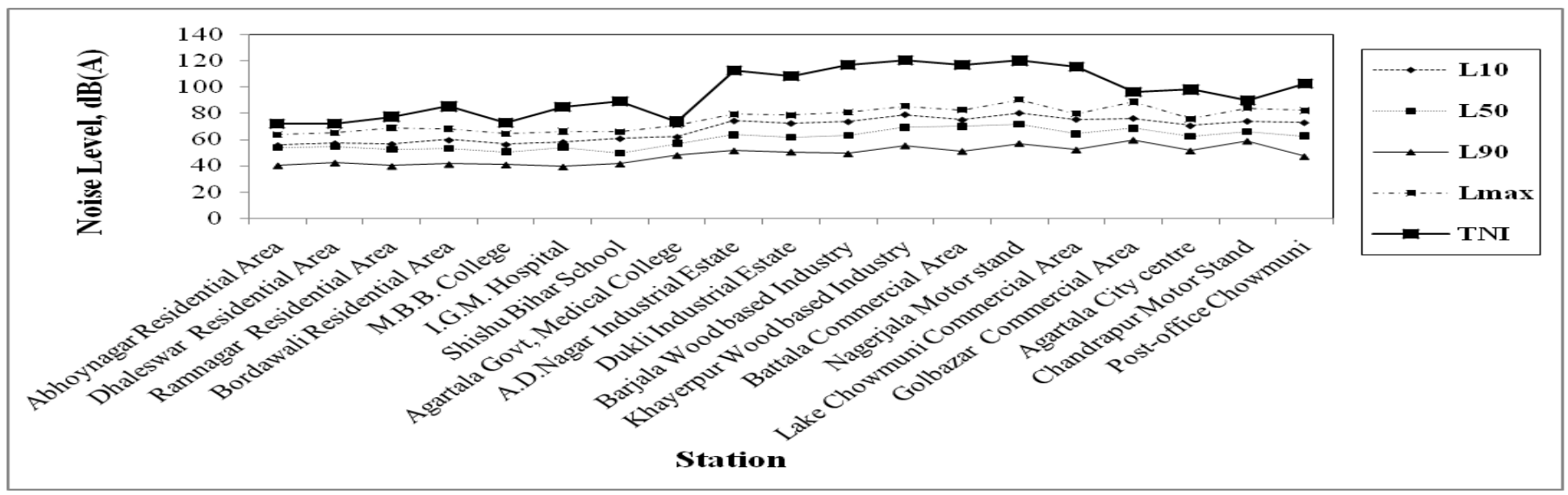

Fig: 6 Noise Levels at different places

\section{CONCLUSIONS}

The present study is restricted to Agartala City. It is also confined to assess the current status and trend of noise pollution level in Agartala city. However, there exists a strong chance of enhanced noise pollution at the time festive season. Uses of loud speaker, microphones have become a regular phenomenon for various religious activities in Tripura particularly at the Agartala city. Therefore, certain restrictions are necessary for use of loud speaker, microphones in any occasions. At the same time, adequate preventive measures are necessary to cope with the problem associated with noise pollution. The study finds that certain restriction on the use of sound generating instruments, mass awareness among people and regular enforcement of Noise Pollution (Prevention \& Control) Rules 2000 will seek a solution of noise pollution problems of the Agartala City.

\section{ACKNOWLEDGMENTS}

The authors express their sincere thanks to Dr. Srimanta Ray, Assistant Professor, department of chemical engineering, NIT Agartala and Amarendra Jamatia, Assistant Environmental Engineer, Tripura State Pollution Control Board, India for their valuable co-operation to carry out the work smoothly.

\section{REFFERENCES}

[1]. Jamrah A., Al-Omari A., Sharabi R. (2006). Evaluation of traffic noise pollution in Amman, Jordan. Environ Monit Assess. volume 120(1-3):499-525.

[2]. Murthy K. V., Majumder K. A., Khanal N. S., Subedi P. D. (2007). Assessment Of Traffic Noise Pollution In Banepa, A Semi Urban Town Of Nepal. Kathmandu University Journal of Science, Engineering And Technology,VOL.I, No.IV.

[3]. Hassan A., Alam B. J.(2013). Traffic Noise Levels at Different Locations in Dhaka City and Noise Modelling for Construction Equipments. International Journal of Engineering Research and Applications (IJERA).Vol. 3(2), pp.1032-1040.
[4]. Sampath S., Das M. S. and Kumar S. V. (2004). Ambient noise levels in Major cities in Kerala. J.I nd. Geophys. Union. Vol. 8(4), pp-293-298.

[5]. Anomohanran O. (2013). Evaluation of environmental noise pollution in Abuja, the capital city of Nigeria. International Journal of Research and Reviews in Applied Sciences, Volume 14 (2), pp-470-476.

[6]. Mangalekar S.B., Jadhav A.S. and Raut P.D. (2012). Study of Noise Pollution in Kolhapur City, Maharashtra, India. Universal Journal of Environmental Research and Technology . Volume 2(1), pp- 65-69.

[7]. Haq A. M., Islam M. M, Ali S. M., Haque F. M. and M. M. R. Akhand. (2012). Status of Noise Pollution in Mixed Areas of Dhaka City: a GIS Approach. Journal of Environmental Science \& Natural Resources, 5(1): 09-17.

[8]. Central Pollution Control Board, Ministry of Environment and Forests (GOI). The Noise Pollution (Regulation and control) Rules, 2000. The Principal Rules were published in the Gazette of India, vode S.O. 123(E), dated 14.2.2000 and subsequently amended vide S.O. 1046(E), dated 22.11.2000, S.O. 1088(E), dated 11.10.2002, S.O. 1569(E), dated 19.09.2006 and S.O, 50 (E) dated 11.01.2010 under the Environment (Protection) Act, 1986.

[9]. Garg S. K. and Garg R., (2010). Environmental Engineering (vol.II)- Sewage Disposal and Air pollution Engineering. Khanna Publishers. Page $848-849$. 